\title{
Reinventing Ourselves: New and Emerging Roles of Academic Librarians in Canadian Research- Intensive Universities
}

\author{
Ada Ducas, Nicole Michaud-Oystryk, and Marie Speare
}

\begin{abstract}
The academic library profession is being redefined by the shifting research and scholarly landscape, the transformation in higher education, and advances in technology.

A survey of librarians working in Canada's research-intensive universities was conducted to explore new and emerging roles. This study focuses on librarians' activities in: Research Support, Teaching and Learning, Digital Scholarship, User Experience, and Scholarly Communication. It addresses the scope and nature of the new roles, the skills required to provide new services, and the confidence librarians have in their abilities to perform the new roles. It also reports on librarians' job satisfaction and their perceived impact on the academic enterprise.
\end{abstract}

\section{Introduction}

Librarians' roles have naturally changed and evolved through time. However, during the past decade, the dramatic transformation in higher education, the ever-shifting research and scholarly landscape, and the unrelenting advances in technology have had a significant impact on the responsibilities of academic librarians.

In response to societal changes and financial constraints, universities have established new institutional priorities and have committed to enriching the student experience and supporting their success better. This new academic environment, along with the rise of alternative publishing models, the explosion of digital and licensed resources, the creation of digital content, and the ubiquitous presence of social media, challenge librarians to rethink their roles. Recent demands by government agencies to have publications resulting from funded research made

\footnotetext{
*Ada Ducas is Librarian Emerita and Former Head, Health Sciences Libraries, at University of Manitoba; email: ada.ducas@umanitoba.ca. Nicole Michaud-Oystryk is Librarian Emerita and Former Head, Elizabeth Dafoe, St. John's College and St. Paul's College Libraries, at University of Manitoba; email: nicole.michaud-oystryk@umanitoba. ca. Marie Speare is Liaison Librarian, Sciences and Technology Library, at University of Manitoba; email: marie. speare@umanitoba.ca. The authors thank the librarians who took the time to share their experiences and insights by responding to the survey and those who pretested the survey and provided feedback on the manuscript. They also acknowledge the financial support of the Social Sciences and Humanities Research Council of Canada and the University of Manitoba through a UM/SSHRC research grant and the data analyses and contributions of the Statistical Consulting Service (SCS), Department of Statistics, Faculty of Science, University of Manitoba. (C2020 Ada Ducas, Nicole Michaud-Oystryk, and Marie Speare, Attribution-NonCommercial (http://creativecommons. org/licenses/by-nc/4.0/) CC BY-NC.
} 
freely available and research data deposited into an accessible repository or database have created new opportunities for librarians and encouraged their involvement in the lifecycle of research data.

Librarians are adapting to this new environment by collaborating with faculty in research, teaching, and scholarship and striving to enhance the user experience. Traditional functions such as reference work and collection management are rapidly losing their status as primary responsibilities of librarians, while new functions related to research support, data management, bibliometrics, digital initiatives, scholarly communication, and user experience are increasingly becoming part of the academic librarian's responsibilities. While librarians in many institutions have adopted some of the new functions and are in the process of reinventing their roles, others are in the early stages of doing so.

Although the literature abounds with articles on the new and emerging roles of librarians in academic institutions, there is a dearth of research on Canadian academic librarians' changing roles and responsibilities. The present study aims to address this gap by exploring role and responsibility changes as experienced by librarians in Canada's 15 research-intensive universities (U15). ${ }^{1}$ This article presents the results of a survey designed to meet the following objectives: identify librarians' new and emerging roles, gauge confidence levels of librarians in new roles, identify librarians' training needs, measure librarians' job satisfaction relative to new roles, and report on librarians' perceived impact of their roles on the academic enterprise.

\section{Canadian Context}

The target population for the survey are librarians working in the U15 libraries. These libraries are members of the Canadian Association of Research Libraries (CARL), and 13 of the 15 institutions whose librarians were surveyed are members of the Association of Research Libraries (ARL). These libraries all belong to publicly funded universities that rely primarily on government funding and tuition fees to deliver programs. Academic librarians in Canada enjoy academic status that includes tenure or a form of continuing appointment and the right to participate in university governance. ${ }^{2}$

In the Canadian context, research support and scholarly communication are heavily influenced by the three main governmental granting agencies that are referred to as the Tri-Agency. These granting agencies include the National Sciences and Engineering Research Council (NSERC), the Social Sciences and Humanities Research Council (SSHRC), and the Canadian Institutes of Health Research (CIHR). Since 2008, CIHR has had an open access policy, which requires grant recipients to make their final peer-reviewed manuscript available within 12 months of publication. This open access policy was extended to NSERC- and SSHRC-funded research for all grants awarded after May 1, 2015. ${ }^{3}$ In 2018, these agencies developed a draft Tri-Agency Research Data Management Policy, which includes suggestions for institutional data management strategies, researcher data management plans, and data deposit. The policy is still under review and is not currently in effect. ${ }^{4}$ While this study was conducted in Canadian research intensive universities, the survey results should be of interest to other ARL libraries, as the institutions have many similar functions. The main difference between Canada and the United States is that the requirements for open access and data management by the main granting agencies in Canada is still relatively new and compliance is low. ${ }^{5}$

Scholarly communication is an area that has received a great deal of attention from Canadian postsecondary institutions. CARL has been instrumental in addressing issues related 
to scholarly communication and the role of academic libraries. Much of its work in recent years has focused on open access publishing and the creation of a sustainable scholarly communication system in Canada. ${ }^{6}$

In regard to digital scholarship, U15 libraries are at different stages of developing services in this area. While many libraries offer this assistance from multiple service points, others such as McMaster University Library and the University of Alberta Libraries are delivering or planning to deliver these services from a central collaborative space. ${ }^{7}$

Teaching is a core function of most Canadian academic librarians. A 2014 Canadian Association of University Teachers (CAUT) survey reports that 93.53 percent of librarians in Canada indicate at least some teaching or instructional activities as part of their workload. ${ }^{8}$

In the past decade, Canadian postsecondary institutions have increasingly focused on enhancing the user experience in both physical and virtual spaces. U15 libraries have redesigned and repurposed library spaces, with some having recently launched large-scale master plans to modernize their facilities (examples: McGill University and University of Saskatchewan). ${ }^{9}$ Overall, libraries have implemented a wide range of student engagement initiatives and introduced new technology-based services.

\section{Literature Review}

The seminal Association of Research Libraries (ARL) publication New Roles for New Times: Transforming Liaison Roles in Research Libraries served as the initial foundation document for this study in that it identified and helped to delineate new and emerging roles of liaison librarians in the areas of investigation. ${ }^{10}$

During the past decade, a number of studies have provided snapshots of librarians' roles and activities. Nero and Langley, in their benchmark study, create an open access data set that provides a record of what an academic librarian does in the early 21 st century. ${ }^{11}$ Gwyer performs a retrospective analysis of published literature looking at how librarianship has changed and projects future trends. ${ }^{12}$ Cox and Corrall describe how academic librarianship has evolved in the last two decades and how new academic library specialties have developed. ${ }^{13}$ In a systematic review investigating the changing roles of health sciences librarians, Cooper and Crum find "sixteen new roles or activities ... and four new twists in traditional roles." 14

The literature reporting on librarians' emerging roles in research support has surged in the last decade, with many earlier publications illustrating the burgeoning discussion. ${ }^{15} \mathrm{~A}$ 2013 study by Corrall, Kennan, and Afzal explores bibliometrics and data support activities in academic libraries in Australia, New Zealand, Ireland, and the UK and finds a skills deficit and low confidence levels among librarians. ${ }^{16}$ In 2014, they further analyze their data to find out how librarians will meet the demand for more research support services and develop their skills and knowledge. ${ }^{17}$ In their 2012 survey, Cox and Pinfield gauge UK academic libraries' involvement in and challenges of research data management and compare their survey results with those of Corrall et al. and Tenopir, Birch, and Allard. ${ }^{18}$ This study by Tenopir et al. reports the results of a survey of ACRL members "to provide a baseline assessment of the current state of and future plans for research data services." ${ }^{19}$ Three additional articles by Tenopir et al. focus on research data services provided, librarians' preparedness to deliver these services, and their attitudes toward the importance of this activity. ${ }^{20}$ More recently, Tenopir et al. explore the situation in European academic libraries to determine what research data services are currently offered and planned for the future. ${ }^{21}$ In 2017, Cox et al. offer an 
international perspective with a survey on "research data management (RDM) activities, services, and capabilities ... in Australia, Canada, Germany, Ireland, the Netherlands, New Zealand, and the UK." ${ }^{22}$ In another wide-ranging study, Keller examines the development and sustainability of research support services in Australian university libraries and compares the developments in Australia with those in three European countries. ${ }^{23}$ Other studies have a more specific focus. Among these is Auckland's survey of subject librarians and managers in the Research Libraries UK member libraries that examines the role of librarians in meeting researchers' needs and identifies challenges associated with skills gaps. ${ }^{24}$ Antell et al. explore the involvement of science librarians providing data management services in ARL institutions and gather information about skills requirements. ${ }^{25}$

A few publications that examine teaching functions, knowledge acquisition and application, and confidence in librarians' abilities informed this project. Bewick and Corrall focus on how subject librarians acquire and apply their pedagogical knowledge and examine five teaching activities. ${ }^{26}$ Waite, Gannon-Leary, and Carr investigate the tutoring role of librarians in the online environment. ${ }^{27} \mathrm{~A}$ Canadian survey of librarians reveals that the majority of respondents considered teaching an integral part of their professional identity and concludes that, to gain confidence in their teaching, librarians need more formal education. ${ }^{28}$ More recently, a revisioning of the teaching role where collaboration and leadership are key components is emerging. To that point, ACRL's 2017 document Roles and Strengths of Teaching Librarians promises to transform the role by proposing a holistic, conceptual model with seven interconnected roles and identifying the strengths required to fulfill each of these roles. ${ }^{29} \mathrm{~A}$ precursor to this critical document is an article by Bowles-Terry and Donovan in which they advocate for a proactive and collaborative role in which librarians achieve their "potential as pedagogical experts and instructional consultants." 30

Studies going back to 2012 promote the role of librarians in digital scholarship and their capacity to engage and become effective partners. Vandegrift focuses on the role of digital humanities in the library, promoting the idea of moving from a "service" model to a "production" model. ${ }^{31}$ His later article, coauthored with Varner, continues to make the case that digital humanities and libraries are natural scholarly partners. ${ }^{32}$ Sula presents a conceptual model of libraries and digital humanities coming together where librarians can engage in and perform the work of digital humanities. ${ }^{33}$ More recently, a 2015 survey of academic librarians and faculty conducted by Cengage Learning and American Libraries provides an important measure in time. ${ }^{34}$ The survey identifies support services and challenges, including staffing issues. It establishes a preference for a model where the library is a research partner rather than a service provider. Finally, King proposes a new role that combines digital librarian and digital humanist, underscoring the librarian's capacity to be an equal partner in the process. ${ }^{35}$

Until recently, many publications on user experience describe the experience that students and faculty have with online interfaces, websites, and virtual library services. During the past few years, user experience (UX) has become its own specialty encompassing a more holistic view of service. In two related articles, Bell advocates that "Academic librarians should look for ways to improve processes to make using the library more seamless, convenient and time saving" 36 and encourages librarians to adopt a design orientation that will result in "an experience that leverages the library's unique elements that are impossible to obtain elsewhere." ${ }^{37}$ To understand the new UX specialization, MacDonald conducted a qualitative study involving interviews with 16 librarians who have "User Experience" in their titles. His report provides 
a timely snapshot of this developing role. ${ }^{38}$ He further expands on this work when he delves into the factors that led to the emphasis on UX and its benefits and challenges. ${ }^{39}$

As librarians shift from collecting, organizing, and preserving materials to creating, sharing, disseminating, and curating knowledge, new roles related to scholarly communication are emerging. In a survey of repository managers in Italy, Cassella and Morando assess the roles and skills required to implement and manage institutional repositories. ${ }^{40}$ Looking into the future, Chadwell and Sutton see libraries shifting from being "consumers of information to becoming disseminators of scholarship" ${ }^{41}$ and envision how open access and library publishing will create new roles for librarians. Not all librarians are ready to assume these roles. An Israeli study by Klain-Gabbay and Shoham finds that approximately one-third of the librarians surveyed appear to be uninterested or underestimate their capabilities to be actively involved in scholarly communication. ${ }^{42}$

A large body of literature examines how prepared librarians are and what new skills they require to perform their roles. ${ }^{43}$ Researchers such as Riley-Huff and Rholes investigate librarian readiness and methods librarians have used to acquire their skills, ${ }^{44}$ and Hess describes job-embedded professional learning. ${ }^{45}$ Several articles address the fact that, for librarians to perform their new roles, pedagogic theory needs to be integrated into their training. ${ }^{46}$ The one anomaly appears in Bewick and Corrall's study, where the majority of UK librarians report that they have sufficient knowledge to fulfill their roles. ${ }^{47}$

There are very few comprehensive studies investigating academic librarians' overall job satisfaction that relate to the current research. One is a 20 -year-old Canadian study by Leckie and Brett that explores job satisfaction of Canadian university librarians replicating Horenstein's study of American librarians. ${ }^{48}$ Both studies report that the single most satisfactory element of their work is their relationship with their clientele.

There is an overwhelming number of articles dealing with the impact of librarians on the academic enterprise. For the purpose of the current study, Robertson's article is relevant. His interview of provosts from nine U15 Canadian universities quantifies their perceptions of their libraries' contribution to institutional priorities. ${ }^{49}$ They share their belief that librarians should take on a greater collaborative role with faculty and teaching support units around pedagogical developments. They discuss the changing roles of librarians and the need for librarians to become active as embedded partners in teaching, research, and learning activities of the university.

\section{Methodology}

A survey was sent to 743 academic librarians, including archivists, working in Canada's U15 universities. The U15 identify themselves as Canada's leading research-intensive institutions that conduct 80 percent of all competitive university research. They consist of 12 English-language and two French-language universities and one officially bilingual university. These universities were selected to make the project manageable and to obtain responses from librarians employed by institutions with similar missions. Senior library administrators (that is, university librarians, deans, directors, and their associates) were not included in the survey population.

The survey is an attempt at a census; therefore, the results are representative only of those who responded and are to be viewed as descriptive in nature. Respondents were assured that their replies would be kept confidential and that the study had been reviewed and approved by the University of Manitoba's Research Ethics Board. SurveyMonkey was selected as the 
survey software, and SPSS, IBM SPSS Statistics Version 24, and R, RStudio Version 1.1.447 statistical software were used to analyze the data. Cronbach's alpha test was used to measure the reliability of the survey. The following tests were also used for different aspects of the data analysis: ANOVA and Pearson Chi-square tests, Kruskal-Wallis test, Dependent (Paired) two-group Wilcoxon Signed Rank Test, and Independent two-group Mann Whitney U test. The statistical software used were recommended by the University of Manitoba's Statistical Consulting Services. The survey questionnaire and the data are stored in the University of Manitoba's Dataverse repository and are available for use.

\section{Survey Instrument}

A 38-question survey was designed in English and French. The survey gathered demographic information and addressed five areas of investigation: Research Support, Teaching and Learning, Digital Scholarship, User Experience, and Scholarly Communication. These areas and the functions related to each of them were identified primarily in the ARL publication, New Roles for New Times: Transforming Liaison Roles on Research Libraries. ${ }^{50}$ Additional functions were identified through a review of the literature and job postings. Within each of the areas of investigation, respondents were asked which functions they perform, how confident they are in their abilities to carry out these functions, how they acquired the skills to do their work, and where they require more training. Respondents were also invited to state whether they perform a traditional or a new role and to assess the amount of time they spend on either role. They were then asked how satisfied they are with their position and what impact they believe they have on the academic enterprise. For the most part, the questions were close-ended; the most probable choices were provided, and respondents were invited to check as many as applied. Respondents were also given the opportunity to provide additional possibilities in an "other" option and to submit general comments at the end.

Seven librarians and archivists from both English- and French-language institutions piloted the survey. After some adjustments, the final survey was distributed in March 2017, with reminders sent in the following two weeks. The distribution list was created using the CAPAL (Canadian Association of Professional Academic Librarians) membership directory and staff listings on each of the U15 libraries' websites.

The Cronbach's alpha was used to measure the reliability of the survey questions, and it was determined that the responses to the librarians' confidence level questions have high reliability with Cronbach's alpha $=.735$, as do the responses to the questions related to the librarians' job satisfaction in performing traditional and new roles, with Cronbach's alpha $=$ .908 and .934, respectively; and the responses to the questions related to the impact librarians performing traditional and new roles have on the academic enterprise have high reliability as well, with Cronbach's alpha $=.842$ and .761 , respectively. In summary, the instrument is a reliable and valid tool for the survey and study.

\section{Profile of Respondents}

A total of 205 of 743 librarians completed the survey, garnering an overall 27 percent response rate. Responses were received from every U15 university, with individual university response rates ranging from 14 to 51 percent. Some librarians did not respond to all questions; hence, there are a small number of missing values.

A profile of the respondents reveals the following information: 
- 52 percent $(\mathrm{n}=105)$ have up to 10 years of experience working in a postsecondary institution;

- The largest number of respondents $(36 \%$, or $n=73)$ have been working in their current position between 4 and 10 years;

- 36 percent $(n=73)$ have an additional master's degree and 6 percent $(n=12)$ have a PhD.

\section{Results}

This study focuses on five areas where there has been a significant shift in librarians' roles in recent years: Research Support, Teaching and Learning, Digital Scholarship, User Experience, and Scholarly Communication.

\begin{tabular}{|c|c|c|}
\hline \multicolumn{3}{|l|}{$\begin{array}{c}\text { TABLE } 1 \\
\text { Research Support }\end{array}$} \\
\hline Services Provided & Percent & $\begin{array}{c}\text { Number of } \\
\text { Respondents }\end{array}$ \\
\hline \multicolumn{3}{|l|}{ General: 204 respondents } \\
\hline Information discovery, such as consultations and literature reviews & $75.00 \%$ & 153 \\
\hline Grant application support & $28.43 \%$ & 58 \\
\hline Systematic reviews & $27.45 \%$ & 56 \\
\hline Bibliometrics services & $26.47 \%$ & 54 \\
\hline Data management & $22.55 \%$ & 46 \\
\hline None of the above & $15.20 \%$ & 31 \\
\hline \multicolumn{3}{|l|}{ Data Management: 164 respondents } \\
\hline Assistance with use of technology, infrastructure, and tools & $26.22 \%$ & 43 \\
\hline Support for data deposit in your institutional repository & $25.61 \%$ & 42 \\
\hline Finding external data sets & $21.95 \%$ & 36 \\
\hline Development of data management plans & $18.90 \%$ & 31 \\
\hline Guidance on the handling and management of unpublished data & $14.63 \%$ & 24 \\
\hline Assistance with technical aspects of digital curation & $14.02 \%$ & 23 \\
\hline Development of institutional policy to manage data & $8.54 \%$ & 14 \\
\hline Support for data deposit in external repositories or data archives & $8.54 \%$ & 14 \\
\hline Development of tools to assist researchers manage their data & $6.10 \%$ & 10 \\
\hline None of the above & $45.73 \%$ & 75 \\
\hline \multicolumn{3}{|l|}{ Bibliometric Services: 157 respondents } \\
\hline Bibliometrics training & $29.94 \%$ & 47 \\
\hline Citation reports & $27.39 \%$ & 43 \\
\hline Altmetrics support & $24.84 \%$ & 39 \\
\hline Calculation of research impact & $22.29 \%$ & 35 \\
\hline $\mathrm{H}$-index calculations & $21.66 \%$ & 34 \\
\hline E-research support for recruitment, promotion, or tenure application & $8.28 \%$ & 13 \\
\hline Disciplinary research trends reports & $7.01 \%$ & 11 \\
\hline None of the above & $49.68 \%$ & 78 \\
\hline
\end{tabular}




\section{Research Support}

The first area of investigation is Research Support, which includes information discovery, systematic reviews, grant application support, as well as various aspects of bibliometrics, and data management. Of the 204 respondents, 173 stated that they provide one or more of the services offered as options with 31 stating that they did not provide any of the services (see Table 1). Overwhelmingly, 75 percent $^{51}(\mathrm{n}=153)$ of the respondents reported information discovery, e.g. consultations and literature reviews as a service they offer. Respondents reported delivering the other services at comparable rates ranging from $23-28$ percent ( $\mathrm{n}=46$ to 58 ).

A more detailed analysis of data management and bibliometrics was performed to find out more specifically what aspects of these functions librarians are most likely to provide. The results in table 1 reveal that assistance with the use of technology, infrastructure, and tools at 26 percent $(n=43)$, support for data deposit in institutional repository at 26 percent $(n=42)$, and finding external data sets at 22 percent $(\mathrm{n}=36)$ are the top three data management services provided. Respondents currently seem to be providing what can be more closely characterized as traditional assistance and support functions. They are less involved in the development of data management tools and the development of institutional policies.

The results show that librarians provide bibliometric services at a higher rate than data management. Bibliometrics training is the highest delivered service at 30 percent $(n=47)$, followed by citation reports at 27 percent $(n=43)$, and altmetrics at 25 percent $(n=39)$. Twenty-two percent of the respondents provide calculation of research impact $(\mathrm{n}=35)$ and $h$-index calculations $(\mathrm{n}=34)$.

\section{Teaching and Learning}

For the second area of investigation, Teaching and Learning, functions beyond the traditional bibliographic instruction and orientation were explored. Twelve services were offered as options. Of the 190 respondents, 168 stated that they provide one or more of the proposed services, and 22 reported that they did not provide any of these services.

As table 2 indicates, the two services, classroom teaching to students and one-on-one teaching, selected by the highest number of respondents at 78 percent $(n=149)$ and 75 percent $(n$ $=142$ ) respectively, could be seen as more traditional than new. However, a considerable number of respondents ranging from 43 to 48 percent deliver emerging services: copyright consultation $(\mathrm{n}=82)$, teaching workshops for faculty $(\mathrm{n}=90)$, and tutorials $(\mathrm{n}=92)$. As for what could be considered newer roles, the highest responses are for instructional design $(\mathrm{n}=47)$, participation in course management systems $(\mathrm{n}=69)$, online learning $(\mathrm{n}=73)$, and short videos, screencasts $(n=74)$, ranging from 25 to

\begin{tabular}{|l|c|c|}
\hline \multicolumn{3}{|c|}{ TABLE 2} \\
\hline Teaching and Learning: 190 respondents \\
\hline Services Provided & Percent & $\begin{array}{c}\text { Number of } \\
\text { Respondents }\end{array}$ \\
\hline Classroom teaching to students & $78.42 \%$ & 149 \\
\hline One-on-one teaching & $74.74 \%$ & 142 \\
\hline Tutorials & $48.42 \%$ & 92 \\
\hline Teaching workshops for faculty & $47.37 \%$ & 90 \\
\hline Copyright consultation & $43.16 \%$ & 82 \\
\hline Short videos, screencasts & $38.95 \%$ & 74 \\
\hline Online learning & $38.42 \%$ & 73 \\
\hline $\begin{array}{l}\text { Participation in course } \\
\text { management systems }\end{array}$ & $36.32 \%$ & 69 \\
\hline Instructional design & & \\
\hline Media literacy & $24.74 \%$ & 47 \\
\hline Data literacy & $15.79 \%$ & 30 \\
\hline Mapping and GIS & $15.26 \%$ & 29 \\
\hline None of the above & $4.74 \%$ & 9 \\
\hline
\end{tabular}


39 percent. Not surprisingly, very specialized services such as media literacy, data literacy, and mapping and GIS garnered much lower rates.

\section{Digital Scholarship}

In addressing Digital Scholarship, the survey investigated 11 services relating to the use of advanced computing technologies and digital media to visualize and analyze data and to create new scholarly works. Results show that slightly more than half (103) of the 184 respondents provide one or more of the services offered as options, with 81 providing none of the services. Of the five areas of investigation, Digital Scholarship is the area with the lowest rate of participation. Copyright consultation is provided at 36 percent $(n=67)$, almost double the next highest service that is project development support at 20 percent $(\mathrm{n}=37)$. Text encoding and text mining are very low at 3 percent $(\mathrm{n}=$ $6)$ and 5 percent $(n=10)$ respectively (see table 3).

\section{User Experience}

This survey focuses on questions related to assessment, communication, user-centered design, and liaison with staff and faculty. Of the five areas of investigation, User Experience garnered the highest number of respondents, with 177 stating that they provide one or more of the User Experience functions presented to them (see table 4). Only 7 replied that they did not deliver any of the services listed. Overwhelmingly, the top response is liaison with staff and faculty at 87 percent (n $=160)$, followed by library services assessment at 46 percent $(\mathrm{n}=85)$, and then student engagement initiatives at

\begin{tabular}{|l|c|c|}
\hline \multicolumn{3}{|c|}{ TABLE 3 } \\
\hline Digital Scholarship: 184 respondents \\
\hline Services Provided & Percent & $\begin{array}{c}\text { Number of } \\
\text { Respondents }\end{array}$ \\
\hline Copyright consultation & $36.41 \%$ & 67 \\
\hline Project development support & $20.11 \%$ & 37 \\
\hline Digital preservation & $16.85 \%$ & 31 \\
\hline $\begin{array}{l}\text { Instruction on data } \\
\text { management and preservation }\end{array}$ & $13.59 \%$ & 25 \\
\hline Website management support & $13.59 \%$ & 25 \\
\hline Digital services coordination & $12.50 \%$ & 23 \\
\hline Metadata services & $10.33 \%$ & 19 \\
\hline Data curation & $10.33 \%$ & 19 \\
\hline Electronic-text services & $8.15 \%$ & 15 \\
\hline Text mining & $5.43 \%$ & 10 \\
\hline Text encoding & $3.26 \%$ & 6 \\
\hline None of the above & $44.02 \%$ & 81 \\
\hline
\end{tabular}
41 percent $(n=76)$. Technology-based activities such as communication via social media, user-centered design, and technology assessment garnered respectable results.

\begin{tabular}{|l|c|c|}
\hline \multicolumn{3}{|c|}{ TABLE 4 } \\
\hline User Experience: 184 respondents \\
\hline Services Provided & Percent & $\begin{array}{c}\text { Number of } \\
\text { Respondents }\end{array}$ \\
\hline Liaison with staff and faculty & $86.96 \%$ & 160 \\
\hline Library services assessment & $46.20 \%$ & 85 \\
\hline Student engagement initiatives & $41.30 \%$ & 76 \\
\hline $\begin{array}{l}\text { Communication via social } \\
\text { media }\end{array}$ & $37.50 \%$ & 69 \\
\hline $\begin{array}{l}\text { Website design, accessibility, } \\
\text { usability }\end{array}$ & $34.24 \%$ & 63 \\
\hline User-centred design & $26.09 \%$ & 48 \\
\hline $\begin{array}{l}\text { Physical environment } \\
\text { assessment }\end{array}$ & $23.37 \%$ & 43 \\
\hline Technology assessment & $17.93 \%$ & 33 \\
\hline None of the above & $3.80 \%$ & 7 \\
\hline
\end{tabular}




\section{Scholarly Communication}

The survey aims to find out to what extent Scholarly Communication is part of librarians' responsibilities. Services related to alternative publishing models, funder mandates, copyright, data management, electronic publishing, digital rights, and open educational resources were offered as options. Of the 171 respondents who answered the questions related to Scholarly Communication, 117 stated that they provide one or more of the services offered as options, and 54 chose the none of the above option. Consultation on alternative publishing models, including open access had the highest response rate at 49 percent $(\mathrm{n}=84)$. As in the areas of Teaching and Learning and Digital Scholarship, copyright and intellectual property ranked highly, with a 41 percent $(n=70)$ response rate. Consultation on funder mandates and policies was the next highest service, provided by 26 percent $(n=44)$ of the respondents. Both areas of digital rights management and training in open educational resources recorded limited activity at 10 percent $(n=17)$ (see table 5).

\begin{tabular}{|l|c|c|}
\hline \multicolumn{3}{|c|}{ TABLE 5 } \\
Scholarly Communication: 171 Respondents \\
\hline Services Provided & Percent & $\begin{array}{c}\text { Number of } \\
\text { Respondents }\end{array}$ \\
\hline Consultation on alternative publishing models, including open access & $49.12 \%$ & 84 \\
\hline Copyright and intellectual property & $40.94 \%$ & 70 \\
\hline Consultation on funder mandates and policies & $25.73 \%$ & 44 \\
\hline Data management & $22.22 \%$ & 38 \\
\hline Development and delivery of educational programs & $19.30 \%$ & 33 \\
\hline Electronic publishing & $15.20 \%$ & 26 \\
\hline Digital rights management & $9.94 \%$ & 17 \\
\hline Training in open educational resources & $9.94 \%$ & 17 \\
\hline None of the above & $31.58 \%$ & 54 \\
\hline
\end{tabular}

In summary, the results show that the areas of Research Support $(n=173)$, Teaching and Learning $(n=168)$, and User Experience $(n=177)$ garnered the highest response rates, with librarians indicating that they provide one or more of the services offered as options. Scholarly Communication $(n=117)$ and Digital Scholarship $(n=103)$ received the lowest rates of response.

Overall, most librarians revealed that they perform functions in more than one area. The majority responded to all five areas.

\section{Librarians' Confidence Levels}

After exploring what services or functions librarians fulfill in each of the five areas of investigation, the survey participants were asked how confident they are in their ability to perform their duties in each area. The majority of librarians are either confident or very confident in their abilities. The respondents are most confident in the area of Teaching and Learning, with 75 percent $(n=126)$ of them reporting being confident or very confident, whereas they report considerably lower levels of confidence in the areas of Research Support (62\%, $\mathrm{n}=102)$, User Experience $(60 \%, \mathrm{n}=$ 104), Scholarly Communication ( $51 \%, \mathrm{n}=62)$, and Digital Scholarship $(50 \%, \mathrm{n}=53)$. At the other end of the scale, none of the respondents state that they lack confidence in Teaching and Learning and only 1 percent $(n=2)$ indicate having no confidence in User Experience (see figure 1). 


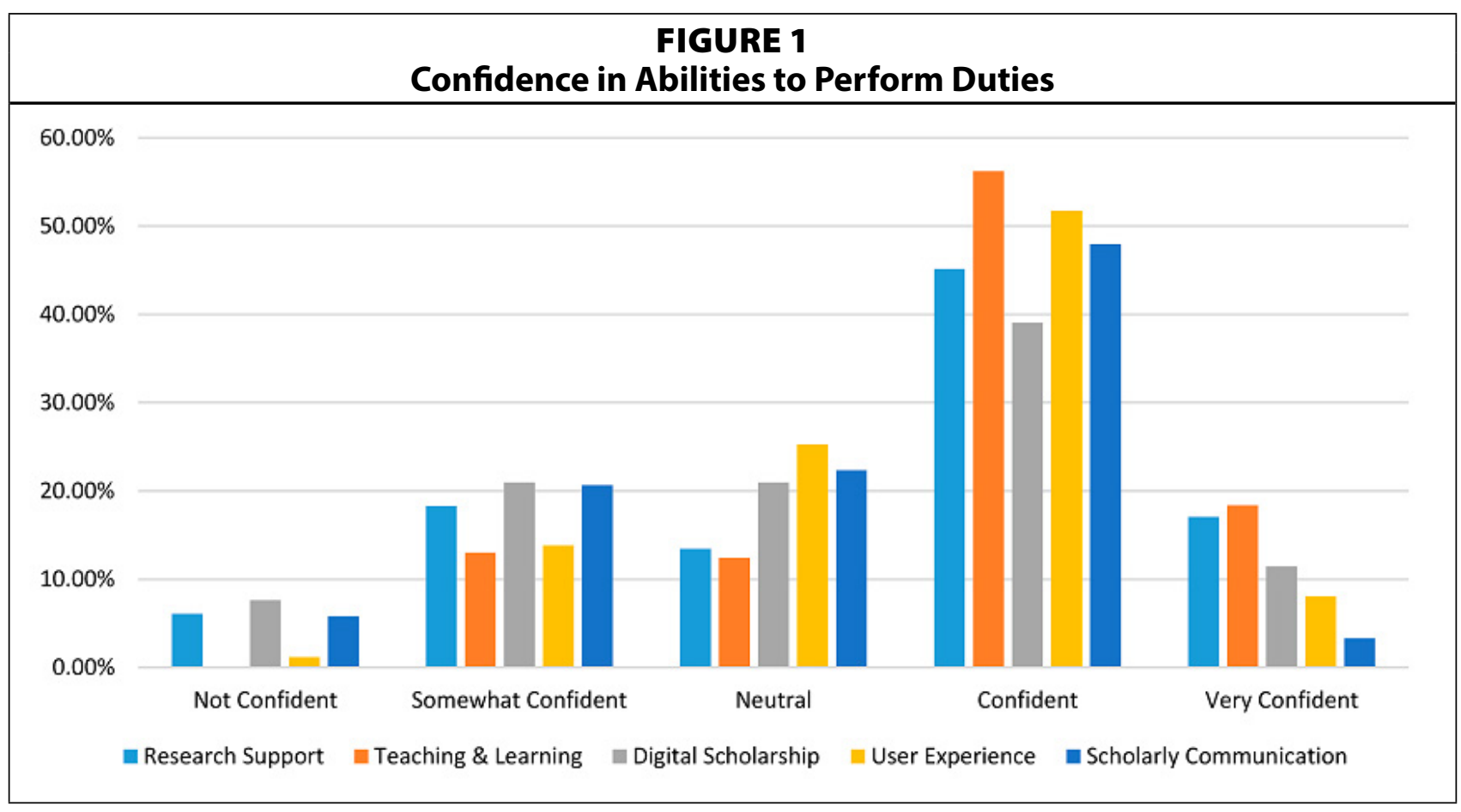

Assuming that there may be a difference between the confidence level and years in current position, five ANOVAChi-square tests were used to find out if there is a relationship between years in current position and each of the five areas of investigation, pairwise and separately. Based on the testing results and on the significance level set at 0.15 , there is no statistically significant relationship between confidence and years in position for Research Support $(P=0.270)$, Teaching and Learning $(P=0.353)$, User Experience $(P=0.523)$, and Scholarly Communication $(P=0.620)$. However, there is statistically sufficient evidence to conclude that there is a relationship between years in current position and confidence levels for Digital Scholarship $(P=0.106)$. (See table 6.)

\begin{tabular}{|l|c|}
\hline \multicolumn{2}{|c|}{$\begin{array}{c}\text { TABLE } 6 \\
\text { Confidence and Years in Current } \\
\text { Position }\end{array}$} \\
\hline Area & P-value* \\
\hline Research Support & 0.27 \\
\hline Teaching and Learning & 0.353 \\
\hline User Experience & 0.523 \\
\hline Scholarly Communication & 0.62 \\
\hline Digital Scholarship & 0.106 \\
\hline $\begin{array}{l}\text { *Significance set at 0.15 and } \\
\text { determined by ANOVA Chi-square tests }\end{array}$ \\
\hline \multicolumn{2}{|c|}{}
\end{tabular}

Additionally, five nonparametric Kruskal-Wallis tests were used to test the difference between the years in current position and the librarians' confidence levels in each of the areas of investigation, pairwise and separately. Based on the testing results and on the significance level set at 0.15 , there is a significant difference in the librarians' confidence levels for Digital Scholarship and years in current position $(P$ $=0.055)$. Librarians that have worked less than one year in their current position have a higher level of confidence in Digital Scholarship than librarians with one or more years of experience. Similarly, while there is no significant difference in the confidence levels for Scholarly Communication, librarians performing those functions and having less than one year of experience were the most confident in their abilities. In the other three areas of investigation, librarians with less than one year of experience in their current position were less confident than librarians with more experience (see table 7). 


\begin{tabular}{|c|c|c|}
\hline \multicolumn{3}{|c|}{$\begin{array}{c}\text { TABLE } 7 \\
\text { Confidence and Years in Current Position }\end{array}$} \\
\hline Area & $\begin{array}{l}\text { Confidence Mean Rank (higher } \\
\text { number = more confidence) }\end{array}$ & Years of Experience \\
\hline \multirow[t]{5}{*}{ Research Support $\left(P=0.877^{*}\right)$} & 84.97 & 4 to 10 years \\
\hline & 81.57 & 11 to 20 years \\
\hline & 80.19 & 1 to 3 years \\
\hline & 75.61 & More than 20 years \\
\hline & 69.78 & Less than 1 year \\
\hline \multirow{5}{*}{$\begin{array}{l}\text { Teaching and Learning }(P= \\
\left.0.417^{*}\right)\end{array}$} & 92.27 & 4 to 10 years \\
\hline & 84.22 & More than 20 years \\
\hline & 81.47 & 11 to 20 years \\
\hline & 78.67 & 1 to 3 years \\
\hline & 71.45 & Less than 1 year \\
\hline \multirow{5}{*}{$\begin{array}{l}\text { Digital Scholarship }(P= \\
\left.0.055^{*}\right)\end{array}$} & 87.80 & Less than 1 year \\
\hline & 54.31 & 1 to 3 years \\
\hline & 51.50 & More than 20 years \\
\hline & 49.52 & 11 to 20 years \\
\hline & 47.00 & 4 to 10 years \\
\hline \multirow{5}{*}{$\begin{array}{l}\text { User Experience } \\
\left(P=0.471^{*}\right)\end{array}$} & 91.63 & 4 to 10 years \\
\hline & 91.08 & More than 20 years \\
\hline & 89.00 & 11 to 20 years \\
\hline & 81.15 & 1 to 3 years \\
\hline & 64.75 & Less than 1 year \\
\hline \multirow{5}{*}{$\begin{array}{l}\text { Scholarly Communication } \\
\left(P=0.518^{*}\right)\end{array}$} & 81.00 & Less than 1 year \\
\hline & 63.75 & More than 20 years \\
\hline & 60.71 & 4 to 10 years \\
\hline & 60.38 & 11 to 20 years \\
\hline & 55.28 & 1 to 3 years \\
\hline
\end{tabular}

\section{Training and Training Needs}

Another objective of the study was to examine how the respondents acquired the skills and knowledge that enable them to perform their duties (see figure 2). Overwhelmingly, respondents stated they acquired their skills primarily through professional work experience and selfteaching. The next highest responses for all areas of investigation were participating in external professional development activities and attending workshops or seminars within the library. Skills and knowledge acquisition through library and information science programs and other formal training is considerably lower. Training provided by vendors or suppliers is ranked the lowest as a means to learn new skills except in the area of Research Support $(29 \%, n=47)$. 


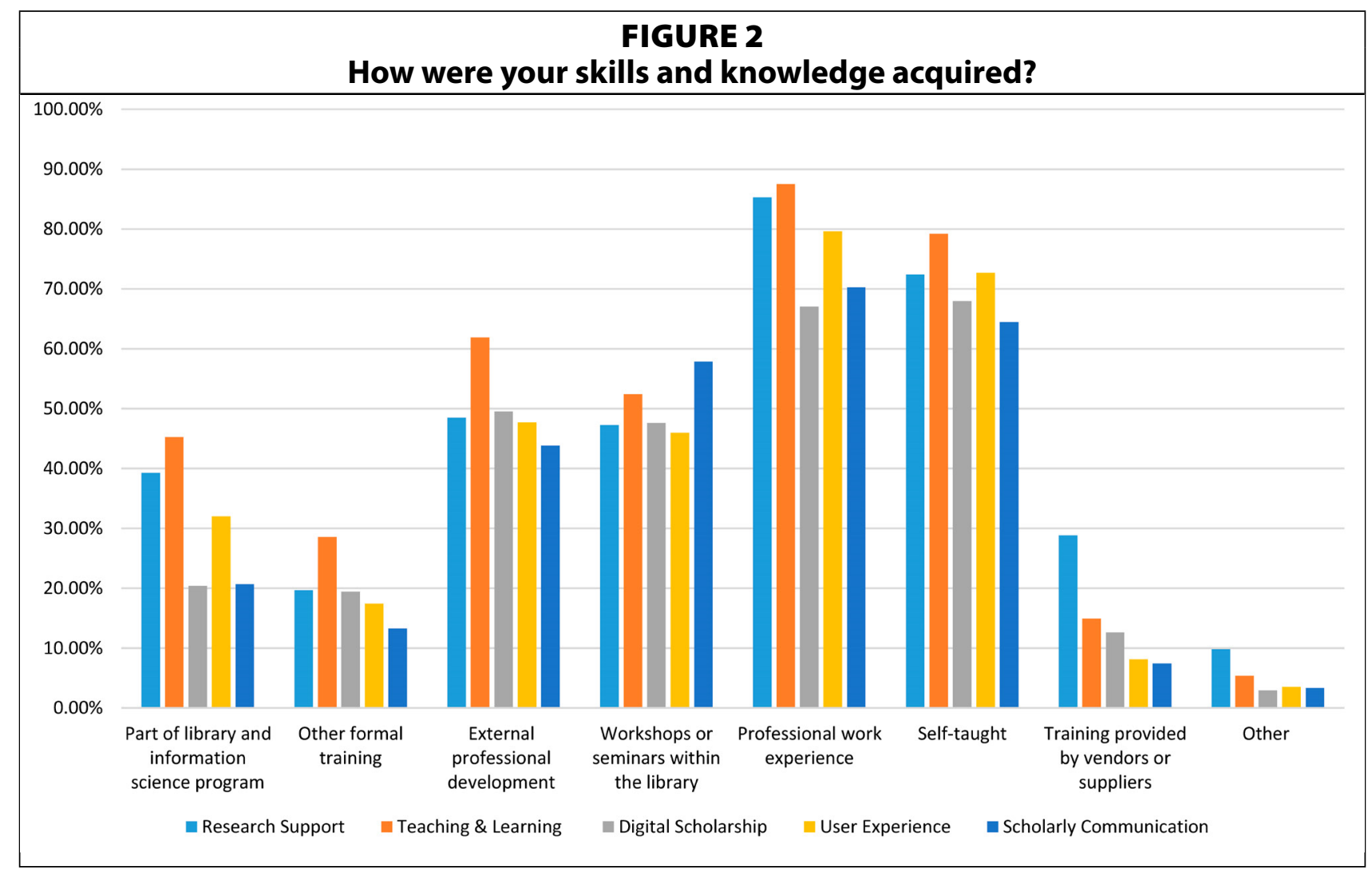

The respondents were asked to indicate what additional training they require to perform their duties in each area of investigation. The results for each area are displayed in descending order of need (see figure 3). Functions that garner more than 50 percent in each area are data curation skills, 62 percent $(\mathrm{n}=99)$; skills in statistics and quantitative methods, 60 percent $(\mathrm{n}=96)$; knowledge of bibliometric tools and techniques, 58 percent $(\mathrm{n}=93)$; text-mining, 56 percent $(\mathrm{n}=58)$; data management (Digital Scholarship), 55 percent $(\mathrm{n}=57)$; assessment methodology and techniques, 56 percent $(\mathrm{n}=95)$; data management (Scholarly Communication), 57 percent $(\mathrm{n}=68)$; digital rights management, 57 percent $(n=68)$. None of the functions in Teaching and Learning received a response rate of more than 50 percent. Not all respondents expressed a need for additional training: 4 percent $(n=6)$ reported that they do not require additional training in Research Support; 7 percent $(n=12)$ in Teaching and Learning; 12 percent $(n=12)$ in Digital Scholarship; 13 percent $(n=22)$ in User Experience, and 7 percent $(n=8)$ in Scholarly Communication.

A small number of the respondents indicated needing training in subject or disciplinary knowledge (Research Support). This could be explained by the fact that, in the collection of demographic information at the beginning of the survey, when asked what functions they fulfill as part of their current responsibilities, $150(74 \%)$ of the librarians reported having liaison/ subject specialist responsibilities.

\section{Traditional vs. New Roles}

Given that most librarians are not performing new or traditional roles exclusively, a major interest of the study was to determine how many librarians are performing new roles (that is, Research Support, Teaching and Learning, Digital Scholarship, User Experience, or Scholarly Communication); how many are performing traditional roles (such as reference, instruction, cataloguing, collection development, or administration); and how many are carrying out hybrid roles that 


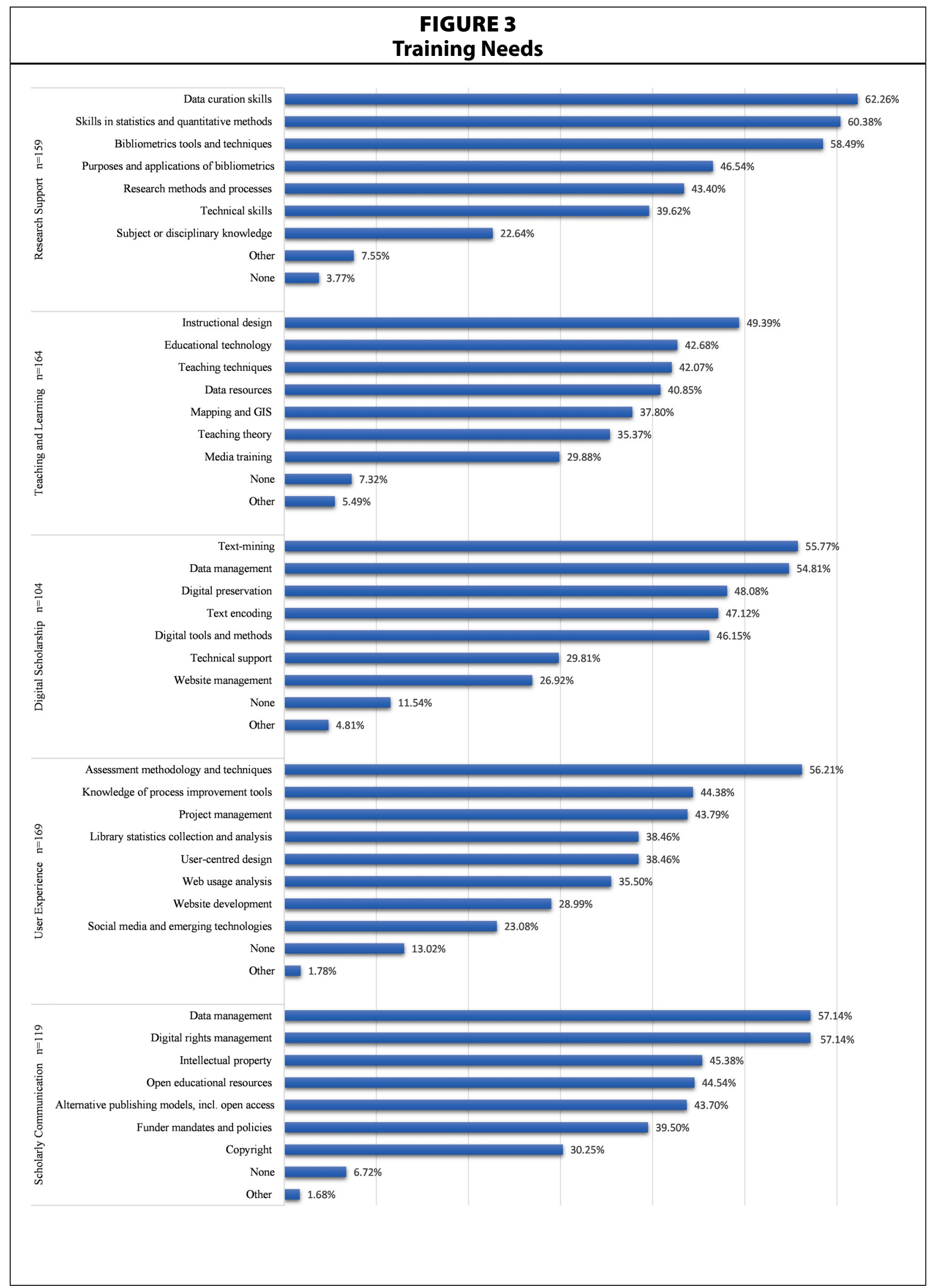


are a combination of new and traditional functions. Of the 205 librarians who completed the survey, $165(80 \%)$ answered the new role or traditional role questions with valid responses (Yes or No). Forty respondents skipped both or answered No for both of these questions; they were excluded when calculating the proportions of librarians who perform either of the traditional and new roles. Results reveal that 21 (13\%) librarians perform only new roles, 72 (44\%) perform only traditional roles, and 72 (44\%) perform hybrid roles. The results also show that 45 percent $(n=79)$ of librarians spend the majority of their time delivering traditional services, 19 percent $(n=33)$ delivering new services, and 36 percent $(n=62)$ spending equal time on both.

\section{Job Satisfaction}

Having asked the respondents if they perform a traditional or a new role, it was deemed important to ask how satisfied the librarians are with the opportunities that their work provides. A Likert scale with the response options of very satisfied, satisfied, neutral, dissatisfied, and very dissatisfied was used to rate several intrinsic aspects of job satisfaction. ${ }^{52}$

For the librarians performing either the traditional or the new roles, the Independent two-group Mann Whitney U Test (W test statistics), with the significance level set at 0.05, was applied to determine significance. The results of the scores (from 1 to 5) for each 5-point Likert scale were ranked and the mean ranks of the new and traditional role groups were computed. The group with the higher mean rank indicates that this group should have a greater number of high scores within it. Table 8 shows that the satisfaction level for both groups is comparable

\begin{tabular}{|c|c|c|c|c|c|c|c|c|}
\hline \multicolumn{9}{|c|}{$\begin{array}{c}\text { TABLE } 8 \\
\text { Satisfaction with Current Position }\end{array}$} \\
\hline \multirow{3}{*}{$\begin{array}{l}\text { Satisfaction } \\
\text { Statements }\end{array}$} & \multirow{3}{*}{\begin{tabular}{|l|}
$\begin{array}{l}\text { Traditional } \\
\text { Only }\end{array}$ \\
Mean rank \\
\end{tabular}} & \multirow{3}{*}{$\begin{array}{l}\text { New } \\
\text { Only } \\
\text { Mean } \\
\text { rank }\end{array}$} & \multirow[b]{3}{*}{$\begin{array}{l}\text { W test } \\
\text { statistics** }\end{array}$} & \multirow[b]{3}{*}{ P-value* } & \multicolumn{4}{|c|}{ Both Traditional and New } \\
\hline & & & & & Traditional & New & & \\
\hline & & & & & Mean rank & $\begin{array}{l}\text { Mean } \\
\text { rank }\end{array}$ & $\begin{array}{l}\text { V test } \\
\text { statistics*** }\end{array}$ & P-value* \\
\hline Assigned duties & 46.06338 & 47.97619 & 714.5 & 0.7517 & 14.6111 & 11 & 88 & 0.009084 \\
\hline $\begin{array}{l}\text { Opportunities for } \\
\text { challenge }\end{array}$ & 43.77083 & 58.07143 & 523.5 & 0.01043 & 16.075 & 14.35 & 143.5 & 0.02499 \\
\hline $\begin{array}{l}\text { Opportunities for } \\
\text { being creative }\end{array}$ & 44.90714 & 49.64286 & 658.5 & 0.4341 & 15.26471 & 16.89286 & 236.5 & 0.8191 \\
\hline $\begin{array}{l}\text { Opportunities for } \\
\text { independent action }\end{array}$ & 45.27083 & 52.92857 & 631.5 & 0.2143 & 11.25 & 15.61765 & 265.5 & 0.02904 \\
\hline $\begin{array}{l}\text { Opportunities to } \\
\text { use your abilities, } \\
\text { education, training }\end{array}$ & 45.52778 & 52.04762 & 650 & 0.2848 & 15.14286 & 15.8125 & 253 & 0.6576 \\
\hline $\begin{array}{l}\text { Opportunities to use } \\
\text { your own judgment }\end{array}$ & 45.31944 & 52.7619 & 635 & 0.2282 & 14.25 & 14.6875 & 235 & 0.4414 \\
\hline $\begin{array}{l}\text { Overall satisfaction } \\
\text { with your work }\end{array}$ & 46.20883 & 49.71429 & 699 & 0.5602 & 14.7 & 13.125 & 157.5 & 0.4201 \\
\hline \multicolumn{9}{|c|}{$\begin{array}{l}\text { *Significance level set at } 0.05 \\
* * \text { W test (Mann Whitney U Test) } \\
* * * V \text { test (Wilcoxon Signed Rank Test) }\end{array}$} \\
\hline
\end{tabular}


in six of the seven areas presented. The only statistically significant finding is that the respondents performing a new role are more satisfied with their opportunities for challenge $(P=0.01043)$.

For the librarians performing both traditional and new roles, the Dependent (Paired) two-group Wilcoxon Signed Rank Test (V test statistics) was applied (see table 8). With the significance level set at 0.05 , the following findings are statistically significant:

- The librarians performing a new role are more satisfied with assigned duties than those performing a traditional role $(P=0.009084)$.

- The librarians performing a new role are more satisfied with opportunities for challenge than those performing a traditional role $(P=0.02499)$.

- The librarians performing a new role are less satisfied with opportunities for independent action than those performing a traditional role $(P=0.02904)$.

\section{Impact on the Academic Enterprise}

Another objective of the study was to determine what impact librarians performing traditional versus new roles believe they are having on the academic enterprise. Using a Likert scale with the response options of substantial, moderate, and low, the respondents were asked to rate a number of impact statements.

Similar to the measure of satisfaction results, the Independent two-group Mann Whitney $\mathrm{U}$ Test (W test statistics), with the significance level set at 0.05 , was applied to determine if there is a significant difference as to how librarians performing either the traditional or the new roles view their impact on the academic enterprise. The results of the scores (from 1 to 5 ) for each 5-point Likert scale were ranked and the mean ranks of the new and traditional role groups were computed. Results indicate that there is no significant difference in the impact level for both groups in any of the six areas presented (see table 9).

\begin{tabular}{|c|c|c|c|c|c|c|c|c|}
\hline \multicolumn{9}{|c|}{$\begin{array}{c}\text { TABLE } 9 \\
\text { Impact on the Academic Enterprise }\end{array}$} \\
\hline \multirow[b]{2}{*}{ Impact Statements } & \multicolumn{4}{|c|}{ Either Traditional or New } & \multicolumn{4}{|c|}{ Both Traditional and New } \\
\hline & Traditional & New & & & Traditional & New & & \\
\hline & Mean rank & \begin{tabular}{|l} 
Mean \\
rank
\end{tabular} & \begin{tabular}{|l|} 
W test \\
statistics**
\end{tabular} & P-value* & Mean rank & $\begin{array}{l}\text { Mean } \\
\text { rank }\end{array}$ & \begin{tabular}{|l|}
$\begin{array}{l}\text { V test } \\
\text { statistics*** }\end{array}$ \\
\end{tabular} & P-value* \\
\hline $\begin{array}{l}\text { Building an effective } \\
\text { partnership with faculty }\end{array}$ & 47.15714 & 42.14286 & 816 & 0.4039 & 13.5 & 13.5 & 202.5 & 0.4413 \\
\hline $\begin{array}{l}\text { Contributing to scholarly } \\
\text { communication }\end{array}$ & 45.82394 & 48.78571 & 697.5 & 0.637 & 9.692308 & 9 & 45 & 0.02621 \\
\hline $\begin{array}{l}\text { Contributing to student } \\
\text { success }\end{array}$ & 46.38732 & 46.88095 & 737.5 & 0.9383 & 12 & 13.31579 & 253 & 0.003686 \\
\hline Supporting researchers & 47.61268 & 42.7381 & 824.5 & 0.4222 & 10.55556 & 10 & 20 & 0.0002126 \\
\hline $\begin{array}{l}\text { Supporting teaching and } \\
\text { learning at the classroom } \\
\text { level }\end{array}$ & 46.14085 & 47.71429 & 720 & 0.8012 & 13.5 & 14.21053 & 270 & 0.01473 \\
\hline $\begin{array}{l}\text { Valuing the role of } \\
\text { academic librarians }\end{array}$ & 45.41429 & 47.95238 & 694 & 0.6752 & 14.25 & 14.6875 & 132.5 & 0.3798 \\
\hline \multicolumn{9}{|c|}{$\begin{array}{l}* \text { Significance level set at } 0.05 \\
* * \text { W test (Mann Whitney U Test) } \\
\text { ***V test (Wilcoxon Signed Rank Test) }\end{array}$} \\
\hline
\end{tabular}


For the librarians performing both the traditional and new roles, the Dependent (Paired) two-group Wilcoxon Signed Rank Test (V test statistics) was applied (see table 9). With the significance level set at 0.05 , the following findings are statistically significant:

- The librarians performing a new role perceived themselves to have more impact on contributing to scholarly communication than those performing a traditional role $(P=0.02621)$.

- The librarians performing a new role perceived themselves to have less impact on contributing to student success than those performing a traditional role $(P=0.003686)$.

- The librarians performing a new role perceived themselves to have more impact on supporting researchers than those performing a traditional role $(P=0.0002126)$.

- The librarians performing a new role perceived themselves to have less impact on supporting teaching and learning at the classroom level than those performing a traditional role $(P=0.01473)$.

\section{Respondents' Comments}

At the end of the survey, the respondents were asked if they had any other comments on the new and emerging roles of academic librarians. Thirty-eight $(19 \%)$ respondents offered a broad range of opinions. Many expressed differing views on the evolution of librarians' roles and the tension that librarians, seemingly liaison or subject librarians, are experiencing in regard to workload, expectations, and sense of value. Some of the concerns expressed follow:

- The new roles are interesting and needed but they tend to result in librarians working in "silos" within their own organization.

- I worry that the subject specialist role is becoming increasingly devalued over time, despite the need for same.

- I believe both the traditional and emerging roles of academic librarians are important. The strength of traditional librarianship model is in the deep knowledge of one's collection and its management... I appreciate the work of functional specialists (copyright, data curation, scholarly communication) and I would like to get to know their roles better so I can refer my faculty to them when there is need.

- It seems that librarians are having to take on new roles in addition to their traditional roles not because they aren't already working at capacity, but because there isn't sufficient funding provided to hire more librarians to take on these newer roles.

- The liaison model is dead, as are traditional library services for the most part. It's time for us to embrace our new role.

- New roles and traditional roles likely need to co-exist and develop together.

- Library management don't understand that liaisons are preferring expanded roles, and that researchers many times don't want to be referred to someone they don't know.

Two other themes emerge in the comments: training and partnership with faculty. As reported earlier under Training and figure 3, part of the research focuses on what additional training librarians require to perform the new functions identified in each of the areas of investigation. It is significant that, notwithstanding this opportunity to articulate their training requirements, several respondents felt compelled to restate this critical need in the comments:

- We need more cross training, and an acknowledgement of impacts on workload.

- ... academic librarians ...need to understand what constitutes research... Our library and information programs have failed to understand this important component... Librarians should be seeking more advance[d] degrees. 
- There is little training support for new and emerging roles-much of the learning is done on the ground and off the side of one's desk; however, this role does suit the professional who enjoys challenges and prefers a pioneering role.

- Opportunities for relevant and targeted support and training in emerging roles is essential for success.

- Le poste dédié à l'évaluation est relativement nouveau (environ 1,5 année) et nous sommes encore dans les débuts. Le programme de maîtrise n'est pas conçu pour préparer les étudiants à un tel poste. Les congrès, les communautés de pratique, les ateliers, la collaboration des collègues, la débrouillardise, etc. sont des alliés précieux. [The position dedicated to assessment is relatively new (about 1.5 years) and we are still in early days. The master's program is not designed to prepare students for such a position. Conferences, communities of practice, workshops, collaboration of colleagues, resourcefulness, etc. are valuable allies.]

A few powerful comments reflect the need for a robust librarian-faculty partnership in the performance of the new and emerging roles:

- ...my experience has confirmed how important it is for librarians to get outside the library to contribute to the broader University community and institutional strategy.

- Librarians must absolutely position themselves as faculty partners in data, digital projects, digital research and teaching. They must propose new models and challenge status quo, providing solutions to the problems faculty actually have and can address... Staying within old roles is a sure death sentence to the profession, and to the library as part of the campus. Anyone in leadership who does not see this is destroying their institution and the careers of the hard-working professionals who are entrusting their futures to the organization.

\section{Discussion}

The study results clearly demonstrate that librarians are still providing many services that relate to traditional rather than new roles: for example, information discovery, classroom teaching, one-on-one teaching, and liaison with staff and faculty garnered among the highest response rates in their respective areas of investigation. This outcome is further reinforced in the area of Digital Scholarship, where results show that, while some librarians are providing digital scholarship services that require more advanced skills, most librarians are still offering their expertise in the more traditional spheres of service.

However, the results also illustrate a transition to the newer roles. Copyright and intellectual property consultation and consultation on alternative publishing models ranked very high, a clear indication that librarians are responding to the changing publishing landscape and are providing services in areas like open access publishing. In addition, there are several areas where more than one-third of the respondents reported activity: bibliometrics training, creating short videos, online learning, participating in course management systems, library services assessment, and communication via social media. Technology-based activities such as user-centered design and technology assessment garnered respectable results, further evidence that librarians have adopted new tools to evaluate user needs and transform the delivery of services. High response rates for these User Experience functions as well as others is not surprising, since transforming library services to meet user needs has always been fundamental to librarianship and most librarians are involved at some level in the delivery of library services. Consultation on funder mandates and policies, a service that will likely grow as adherence to the Canadian Tri-Agency Open Access Policy of 2015 increases, was also selected by a fair 
number of respondents. Nevertheless, results for some of the services provided (for example, mapping and GIS, text-mining, text encoding, and data curation) are very low. This is likely due to the specialized nature of the work and the small number of librarians required by institutions to deliver these services.

Overall, librarians are confident in their abilities to perform the new roles. When the areas of investigation are correlated with the number of years the librarians have been working in their current position, there are no statistically significant differences in their confidence levels except in the area of Digital Scholarship, where the librarians with less experience expressed a higher degree of confidence. One would expect an opposite result; however, this may suggest that libraries have hired librarians who already possess these specialized skills.

The new roles require new skills and knowledge. The survey results reveal that librarians who perform the new roles acquired their competencies primarily through professional work experience or by self-teaching. Understandably, since nearly half of the respondents have been working as librarians for more than 10 years, well before some of the functions that were listed in the survey emerged, they have not received this type of training in LIS schools or held a position requiring it.

Although librarians are confident in performing their new roles, interestingly they also state that their training is clearly insufficient and that they require additional training that will better enable them to provide the new services and to maintain their professional competencies. Very few claim that they require no training. The survey identified many areas in which the librarians require additional training (see figure 3). Data curation skills, statistical training, bibliometrics tools, text mining, data management, assessment methodologies, and digital rights management are the most requested training areas, but there are many other skills that survey respondents identified as being needed. Additionally, in the comments, many of the librarians referred to their subject knowledge as an asset in supporting and in collaborating with faculty and students. They should be offered new and meaningful opportunities to develop the requisite skills that can be used in tandem with their subject expertise.

Library associations and other organizations meet some of the demand by offering inperson and online professional development courses for librarians in the workforce; however, this also represents an opportunity for LIS schools to offer postdegree training both on and off campus to the professional community. While the aforementioned have an important role to play to ensure that learning opportunities are widely available, it is imperative that academic libraries, for their part, firmly support the professional development efforts of their librarians to develop expertise for the new roles.

Even though only a small percentage of the librarians reported performing new roles exclusively, nearly half of the librarians stated that they fulfill both new and traditional roles, revealing that the new roles are gradually being integrated into current practice. The results demonstrate that Canadian librarians performing new or traditional roles have comparable levels of job satisfaction, the only exception being opportunities for challenge where librarians carrying out new roles reported greater satisfaction. This may reflect the fact that being involved in a new endeavor has a level of excitement that is invigorating and rewarding.

Generally, librarians responding to this survey believe that they have a significant impact on the academic enterprise. There is no statistical difference between those performing either a new or a traditional role; however, librarians performing both roles believe their impact is quite different depending on which role they are performing. 
This study's literature review identifies a few studies on the new roles in the area of research data management that include Canadian participants. Unfortunately, the studies by Tenopir et al. that deal with research data services, practices, and skills development do not separately report the responses of Canadian participants, thereby impeding the comparison of their results with those of the present study ${ }^{53}$ The 2017 study by Cox et al. also examines research data management services in seven countries, including Canada. ${ }^{54}$ While it surveyed library directors and not librarians, some of the results are relatable in regard to skills development approaches and needs. With a 23 percent $(n=17)$ response rate from Canada out of a total of 170 responses, it shows support for a wide range of internal and external staff development opportunities that match quite closely the ways the present study's respondents indicate they receive their training outside of professional work experience and self-teaching. It also identifies data curation skills, technical skills, knowledge of research methods, and data description and documentation as high-level needs similar to the current study's respondents who, in relatively large numbers, claim requiring training in these areas.

\section{Conclusion}

This study provides a snapshot in time and establishes a baseline on multiple aspects of librarians' roles in the Canadian academic environment including confidence levels, job satisfaction, and impact on the academic enterprise. While librarians continue to deliver services that are viewed as traditional, they are clearly engaged in the new and emerging roles and are anticipating a greater involvement in the five areas of investigation.

Canadian librarians are generally confident in their abilities to fulfill their new roles, but those performing functions requiring specialized skills report a higher degree of confidence. Despite this level of confidence, the respondents state overwhelmingly that they require additional training. They have a deep awareness of the skills and knowledge, mostly technical in nature, that they need to further their expertise. Professional development at this critical juncture is imperative.

Job satisfaction is comparable among the librarians performing only traditional roles, those performing only new roles, and those performing both roles. The only difference is that those performing solely new roles expressed a higher level of satisfaction in regard to having opportunities for challenge.

Overall, the respondents believe that they have a significant impact on the academic enterprise. This is promising, since, with a greater integration of the new roles, one would expect that, in time, they will see their impact increase.

While the survey results report on the Canadian context, they have the potential of being of benefit to all postsecondary libraries in that they provide a basis for investigation and integration into their specific environments.

What does the future hold? How will the role of the liaison librarian evolve in light of the functional roles librarians are assuming? How will the division between new and traditional roles change over time? What is the actual impact of the new roles that librarians are undertaking? A follow-up study investigating the evolving roles of academic librarians in Canada should be conducted in five to ten years to analyze how librarians have responded to the changing academic environment and reinvented themselves and the profession.

The survey questionnaire and the data from this study are deposited in the University of Manitoba's Dataverse repository, which is available online at https://doi.org/10.5203/FK2/RHOFFU. 


\section{Notes}

1. U15 Group of Canadian Research Universities, Regroupement des universités de recherche du Canada, available online at http://u15.ca/ [accessed 24 May 2018].

2. "Librarians in Canada's Universities \& Colleges State of the Profession 2000-2014," CAUT Education Review ([Ottawa, ON]: Canadian Association of University Teachers, May 2017), available online at https://www.caut. ca/sites/default/files/caut-education-review-2017-05_0.pdf [accessed 13 December 2018].

3. Government of Canada, "Tri-Agency Open Access Policy on Publications" (2016), available online at www. science.gc.ca/eic/site/063.nsf/eng/h_F6765465.html?OpenDocument [accessed 11 December 2018].

4. Government of Canada, "Research Data Management" (2018), available online at www.science.gc.ca/eic/ site/063.nsf/eng/h_547652FB.html [accessed 13 December 2018].

5. Vincent Larivière and Cassidy R. Sugimoto, “Do Authors Comply with Mandates for Open Access ?" Nature 562, no. 7728 (2018): 6-9; Li Zhang and Erin M. Watson, "Measuring the Impact of Gold and Green Open Access," Journal of Academic Librarianship 43, no. 4 (2017): 337-45, https://doi.org/10.1016/j.acalib.2017.06.004; Helen Lasthiotakis, Andrew Kretz, and Creso Sá, “Open Science Strategies in Research Policies: A Comparative Exploration of Canada, the US and the UK," Policy Futures in Education 13, no. 8 (2015): 968-89, https://doi. org/10.1177/1478210315579983.

6. Canadian Association of Research Libraries, "Scholarly Communication" (n.d.), available online at www. carl-abrc.ca/advancing-research/scholarly-communication/ [accessed 11 December 2018].

7. McMaster University Library, "Lewis \& Ruth Sherman Centre for Digital Scholarship" (2018), available online at https://scds.ca/ [accessed 11 December 2018]; University of Alberta Libraries, "Digital Scholarship Centre" (n.d.), available online at https://www.library.ualberta.ca/digital-initiatives/digital-scholarship-centre [accessed 11 December 2018].

8. "Librarians in Canada's Universities \& Colleges State of the Profession 2000-2014."

9. McGill Library, "Master Plan" (n.d.), available online at https://mcgill.ca/library/about/fiat-lux/fiat-luxmaster-plan [accessed 11 November 2019]; University of Saskatchewan, "University Library Transformation Project. Branch Libraries Master Plan" (2017), available online at https://library.usask.ca/documents/UniversityLibraryMasterPlan.pdf [accessed 11 December 2018].

10. Janice M. Jaguszewski and Karen Williams, New Roles for New Times: Transforming Liaison Roles in Research Libraries (Washington, DC: Association of Research Libraries, 2013), available online at https://www.arl.org/wpcontent/uploads/2015/12/nrnt-liaison-roles-revised.pdf [accessed 24 May 2018].

11. Neil Nero and Anne Langley, "Subject Liaisons in Academic Libraries: An Open Access Data Set from 2015," portal: Libraries and the Academy 17, no. 1 (Jan. 2017): 5-15, doi.org/10.1353/pla.2017.0001.

12. Roisin Gwyer, "Identifying and Exploring Future Trends Impacting on Academic Libraries: A Mixed Methodology Using Journal Content Analysis, Focus Groups, and Trend Reports," New Review of Academic Librarianship 21, no. 3 (Sept. 2015): 269-85, doi.org/10.1080/13614533.2015.1026452.

13. Andrew M. Cox and Sheila Corrall, "Evolving Academic Library Specialties," Journal of the American Society for Information Science and Technology 64, no. 8 (2013): 1526-42, doi.org/10.1002/asi.22847.

14. I. Diane Cooper and Janet A. Crum, "New Activities and Changing Roles of Health Sciences Librarians: A Systematic Review, 1990-2012," Journal of the Medical Library Association: JMLA 101, no. 4 (Oct. 2013): 275, doi. org/10.3163/1536-5050.101.4.008.

15. Tracy Gabridge, The Last Mile: Liaison Roles in Curating Science and Engineering Research Data, Research Library Issues, no. 265 (Washington, DC: Association of Research Libraries, 2009): 15-21, doi.org/10.29242/rli.265; Jeremy R. Garritano and Jake R. Carlson, "A Subject Librarian's Guide to Collaborating on e-Science Projects," Issues in Science and Technology Librarianship, no. 57 (Spring 2009), doi.org/10.5062/F42B8VZ3; Margaret Henty, "Dreaming of Data: The Library's Role in Supporting e-Research and Data Management" (paper presented at the Australian Library and Information Association Biennial Conference, Alice Springs, Australia, September 2-5, 2008); Martin Lewis, "Libraries and the Management of Research Data," in Envisioning Future Academic Library Services Initiatives, Ideas and Challenges (London, UK: Facet Publishing, 2010), 145-68; Graham Pryor and Martin Donnelly, "Skilling Up to Do Data: Whose Role, Whose Responsibility, Whose Career?" International Journal of Digital Curation 4, no. 2 (2009): 158-70, doi.org/10.2218/ijdc.v4i2.105; Alma Swan and Sheridan Brown, The Skills, Role and Career Structure of Data Scientists and Curators: An Assessment of Current Practice and Future Needs Report to the JISC (Bristol, UK: Joint Information Systems Committee, 2008), available online at https://eprints.soton. ac.uk/id/eprint/266675 [accessed 24 May 2018].

16. Sheila Corrall, Mary Anne Kennan, and Waseem Afzal, "Bibliometrics and Research Data Management Services: Emerging Trends in Library Support for Research," Library Trends 61, no. 3 (Winter 2013): 636-74, doi. 
org/10.1353/lib.2013.0005.

17. Mary Anne Kennan, Sheila Corrall, and Waseem Afzal, "'Making Space' in Practice and Education: Research Support Services in Academic Libraries," Library Management 35, no. 8/9 (2014): 666-83, https://doi. org/10.1108/LM-03-2014-0037.

18. Andrew M. Cox and Stephen Pinfield, "Research Data Management and Libraries: Current Activities and Future Priorities," Journal of Librarianship and Information Science 46, no. 4 (2014): 299-316, doi. org/10.1177/0961000613492542; Corrall, Kennan, and Afzal, "Bibliometrics and Research Data Management Services," 636-74; Carol Tenopir, Ben Birch, and Suzie Allard, Academic Libraries and Research Data Services: Current Practices and Plans for the Future. An ACRL White Paper (Washington, DC: Association of College \& Research Libraries, 2012), available online at www.ala.org/acrl/sites/ala.org.acrl/files/content/publications/whitepapers/ Tenopir_Birch_Allard.pdf [accessed 13 December 2018].

19. Tenopir et al., Academic Libraries and Research Data Services, 3.

20. Carol Tenopir et al., "Research Data Services in Academic Libraries: Data Intensive Roles for the Future?" Journal of eScience Librarianship 4, no. 2 (2015): e1085, https://doi.org/10.7191/jeslib.2015.1085; Carol Tenopir et al., "Research Data Management Services in Academic Research Libraries and Perceptions of Librarians," Library and Information Science Research 36, no. 2 (2014): 84-90, https://doi.org/10.1016/j.lisr.2013.11.003; Carol Tenopir et al., "Academic Librarians and Research Data Services: Preparation and Attitudes," IFLA Journal 39, no. 1 (2013): 70-78, https://doi.org/10.1177/0340035212473089.

21. Carol Tenopir et al., "Research Data Services in European Academic Research Libraries," Liber Quarterly: The Journal of European Research Libraries 27, no. 1 (2017): 23-44, doi.org/10.18352/lq.10180.

22. Andrew M. Cox et al., "Developments in Research Data Management in Academic Libraries: Towards an Understanding of Research Data Service Maturity," Journal of the Association for Information Science and Technology 68, no. 9 (Sept. 2017): 2182, doi.org/10.1002/asi.23781.

23. Alice Keller, "Research Support in Australian University Libraries: An Outsider View," Australian Academic E Research Libraries 46, no. 2 (2015): 73-85, doi.org/10.1080/00048623.2015.1009528.

24. Mary Auckland, Re-Skilling for Research: An Investigation into the Role and Skills of Subject and Liaison Librarians Required to Effectively Support the Evolving Information Needs of Researchers (London: Research Libraries UK, 2012).

25. Karen Antell et al., “Dealing with Data: Science Librarians' Participation in Data Management at Association of Research Libraries Institutions," College E Research Libraries 75, no. 4 (July 2014): 557-74, doi.org/10.5860/ crl.75.4.557.

26. Laura Bewick and Sheila Corrall, "Developing Librarians as Teachers: A Study of Their Pedagogical Knowledge," Journal of Librarianship and Information Science 42, no. 2 (June 2010): 97-110, doi.org/10.1177/0961000610361419.

27. Kathryn Waite, Pat Gannon-Leary, and James Carr, "The Role and Responsibilities of an E-Tutor Librarian," Journal of Library E Information Services in Distance Learning 5, no. 4 (2011): 129-48, doi.org/10.1080/153329 0X.2011.634980.

28. Heidi Julien and Shelagh K. Genuis, “Librarians' Experiences of the Teaching Role: A National Survey of Librarians," Library E Information Science Research 33, no. 2 (2011): 103-11, doi.org/10.1016/j.lisr.2010.09.005.

29. ACRL, Standards and Proficiencies for Instruction Librarians and Coordinators Revision Task Force, “Roles and Strengths of Teaching Librarians," College E Research Libraries News 78, no. 7 (July-Aug. 2017): 364-70, doi.org/10.5860/crln.78.7.364.

30. Melissa Bowles-Terry and Carrie Donovan, "Serving Notice on the One-Shot: Changing Roles for Instruction Librarians," International Information \& Library Review 48, no. 2 (2016): 137-42, doi.org/10.1080/10572317.2016 .1176457.

31. Micah Vandegrift, "What Is Digital Humanities and What's It Doing in the Library?" In the Library with the Lead Pipe (June 2012): 1-7.

32. Micah Vandegrift and Stewart Varner, "Evolving in Common: Creating Mutually Supportive Relationships Between Libraries and the Digital Humanities," Journal of Library Administration 53, no. 1 (2013): 67-78, doi. org/10.1080/01930826.2013.756699.

33. Chris Alen Sula, "Digital Humanities and Libraries: A Conceptual Model," Journal of Library Administration 53, no. 1 (2013): 10-26, doi.org/10.1080/01930826.2013.756680.

34. Cengage Learning and American Libraries, Digital Humanities: Librarian Survey Results (Boston, MA: Cengage Learning, 2015), available online at https://americanlibrariesmagazine.org/wp-content/uploads/2016/01/ digital-humanities-librarian2.pdf [accessed 24 May 2018].

35. Margaret King, "Digital Scholarship Librarian: What Skills and Competences Are Needed to Be a Collaborative Librarian," International Information E Library Review 50, no. 1 (2018): 40-46, doi.org/10.1080/10572317. 2017.1422898. 
36. Steven Bell, “Delivering a WOW User Experience: Do Academic Librarians Measure Up?" (paper presented at the Association of College and Research Libraries Conference, Philadelphia, March 30-April 2, 2011): 121, available online at www.ala.org/acrl/sites/ala.org.acrl/files/content/conferences/confsandpreconfs/national/2011/ papers/delivering_wow.pdf [accessed 24 May 2018].

37. Steven J. Bell, "Staying True to the Core: Designing the Future Academic Library Experience," portal: Libraries and the Academy 14, no. 3 (July 2014): 376, doi.org/10.1353/pla.2014.0021.

38. Craig M. MacDonald, “User Experience Librarians: User Advocates, User Researchers, Usability Evaluators, or All of the Above?" in Proceedings of the ASISET Annual Meeting (St. Louis, MO: ASIS\&T, 2015), doi.org/10.1002/ pra2.2015.145052010055.

39. Craig M. MacDonald, “'It Takes a Village': On UX Librarianship and Building UX Capacity in Libraries," Journal of Library Administration 57, no. 2 (2017): 194-214, doi.org/10.1080/01930826.2016.1232942.

40. Maria Cassella and Maddalena Morando, "Fostering New Roles for Librarians: Skills Set for Repository Managers: Results of a Survey in Italy," LIBER Quarterly: The Journal of European Research Libraries 21, no. 3/4 (Apr. 2012): 408.

41. Faye Chadwell and Shan C. Sutton, "The Future of Open Access and Library Publishing," New Library World 115, no. 5/6 (2014): 234, doi.org/10.1108/NLW-05-2014-0049.

42. Liat Klain-Gabbay and Snunith Shoham, "Scholarly Communication and Academic Librarians," Library $\mathcal{E}$ Information Science Research 38 (2016): 170-79, https://doi-org.uml.idm.oclc.org/10.1016/j.lisr.2016.04.004.

43. Theresa Westbrock and Sarah Fabian, "Proficiencies for Instruction Librarians: Is There Still a Disconnect Between Professional Education and Professional Responsibilities?" College E Research Libraries 71, no. 6 (Nov. 2010): 569-90, doi.org/10.5860/crl-75r1; Megan M. Bresnahan and Andrew M. Johnson, "Assessing Scholarly Communication and Research Data Training Needs," Reference Services Review 41, no. 3 (2013): 413-33, doi.org/10.1108/ RSR-01-2013-0003; Rebecca A. Brown, Malcolm Wolski, and Joanna Richardson, "Developing New Skills for Research Support Librarians," Australian Library Journal 64, no. 3 (2015): 224-34, doi.org/10.1080/00049670.2015.1 041215; Jacalyn E. Bryan, “The Preparation of Academic Librarians Who Provide Instruction: A Comparison of First and Second Career Librarians," Journal of Academic Librarianship 42, no. 4 (July 2016): 340-54, https://doi-org. uml.idm.oclc.org/10.1016/j.acalib.2016.05.010.

44. Debra A. Riley-Huff and Julia M. Rholes, “Librarians and Technology Skill Acquisition: Issues and Perspectives," Information Technology and Libraries 30, no. 3 (Sept. 2011): 129-40, doi.org/10.6017/ital.v30i3.1770.

45. Amanda Nichols Hess, "A Case Study of Job-Embedded Learning," portal: Libraries and the Academy 16, no. 2 (Apr. 2016): 327-47, available online at https://muse.jhu.edu/article/613845 [accessed 24 May 2018].

46. Cox and Corrall, "Evolving Academic Library Specialties"; Evgenia Vassilakaki and Valentini MoniarouPapaconstantinou, "A Systematic Literature Review Informing Library and Information Professionals' Emerging Roles," New Library World 116, no. 1/2 (Jan. 2015): 37-66"; Bryan, "The Preparation of Academic Librarians Who Provide Instruction."

47. Bewick and Corrall, "Developing Librarians as Teachers."

48. Gloria J. Leckie and Jim Brett, "Job Satisfaction of Canadian University Librarians: A National Survey," College E Research Libraries 58, no. 1 (Jan. 1997): 31-47, doi.org/10.5860/crl.58.1.31; Bonnie Horenstein, “Job Satisfaction of Academic Librarians: An Examination of the Relationships Between Satisfaction, Faculty Status, and Participation," College E Research Libraries 54, no. 3 (May 1993): 255-69, doi.org/10.5860/crl_54_03_255.

49. Mark Robertson, "Perceptions of Canadian Provosts on the Institutional Role of Academic Libraries," College \& Research Libraries 76, no. 4 (May 2015): 490-511, doi.10.5860/crl.76.4.490.

50. Jaguszewski and Williams, New Roles for New Times.

51. Percentages have been rounded in the text. Exact percentages are found in the tables.

52. Leckie and Brett, "Job Satisfaction of Canadian University Librarians"; Horenstein, "Job Satisfaction of Academic Librarians."

53. Tenopir et al., "Academic Librarians and Research Data Services: Preparation and Attitudes"; Tenopir, Birch, and Allard, Academic Libraries and Research Data Services; Tenopir et al., "Research Data Services in Academic Libraries: Data Intensive Roles for the Future?"; Tenopir et al., "Research Data Management Services in Academic Research Libraries and Perceptions of Librarians."

54. Cox et al., "Developments in Research Data Management in Academic Libraries." 